\title{
Evidence That Different Cation Chloride Cotransporters in Retinal Neurons Allow Opposite Responses to GABA
}

\author{
Noga Vardi, ${ }^{1}$ Ling-Li Zhang, ${ }^{1}$ John A. Payne, ${ }^{2}$ and Peter Sterling1 \\ 1 University of Pennsylvania, Department of Neuroscience, Philadelphia, Pennsylvania 19104, and 2University of California, \\ Department of Human Physiology, Davis, California 95616
}

\begin{abstract}
GABA gating an anion channel primarily permeable to chloride can hyperpolarize or depolarize, depending on whether the chloride equilibrium potential $\left(E_{C l}\right)$ is negative or positive, respectively, to the resting membrane potential $\left(E_{\text {rest }}\right)$. If the transmembrane $\mathrm{Cl}^{-}$gradient is set by active transport, those neurons or neuronal regions that exhibit opposite responses to GABA should express different chloride transporters. To test this, we immunostained retina for the $\mathrm{K}-\mathrm{Cl}$ cotransporter (KCC2) that normally extrudes chloride and for the $\mathrm{Na}-\mathrm{K}-\mathrm{Cl}$ cotransporter (NKCC) that normally accumulates chloride. KCC2 was ex-
\end{abstract}

pressed wherever $\mathrm{E}_{\mathrm{Cl}}$ is either known or predicted to be negative to $\mathrm{E}_{\text {rest }}$ (ganglion cells, bipolar axons, and OFF bipolar dendrites), whereas NKCC was expressed wherever $E_{C l}$ is either known or predicted to be positive to $\mathrm{E}_{\text {rest }}$ (horizontal cells and $\mathrm{ON}$ bipolar dendrites). Thus, in the retina, the opposite effects of GABA on different cell types and on different cellular regions are probably primarily determined by the differential targeting of these two chloride transporters.

Key words: GABA depolarization; receptive field; $E_{C I} ; K C C$; NKCC; retinal bipolar cells; horizontal cells
Bipolar cells in vertebrate retina comprise two classes: OFF and ON, so termed because light stimuli drive their membrane potentials in opposite directions. When light decrement on the receptive field center enhances glutamate release from photoreceptors onto bipolar dendritic tips, OFF cells depolarize and ON cells hyperpolarize. When light decrement on the receptive field surround increases GABA release from horizontal cells onto bipolar dendrites (Schwartz, 1982), OFF cells hyperpolarize and ON cells depolarize (Werblin and Dowling, 1969; Kaneko, 1970; Ayoub and Lam, 1984). Because the dendrites of both bipolar classes express GABA $_{\text {A/C }}$ receptors (Chappell et al., 1992; Greferath et al., 1994; Vardi and Sterling, 1994; Enz et al., 1996; Koulen et al., 1998; Shields et al., 2000), one may reasonably infer that GABA contributes to both responses.

How glutamate evokes opposite responses is known; OFF cells depolarize via an ionotropic glutamate receptor that opens a cation channel, whereas $\mathrm{ON}$ cells hyperpolarize via a metabotropic glutamate receptor (mGluR6) that closes a cation channel (Nawy and Jahr, 1990; Shiells and Falk, 1990; Yamashita and Wässle, 1991a; de la Villa et al., 1995). However, how GABA might evoke opposite responses for the surround has been a mystery. Both bipolar classes express ionotropic GABA receptors that open a chloride channel, so opposite responses to GABA cannot arise from different gating properties of the receptor.

GABA would evoke opposite responses if chloride equilibrium potential $\left(\mathrm{E}_{\mathrm{Cl}}\right)$ in the two bipolar classes were on opposite sides of the resting potential $\left(\mathrm{E}_{\text {rest }}\right)$ (Vardi and Sterling, 1994). Thus, GABA would hyperpolarize an OFF cell if $\mathrm{E}_{\mathrm{Cl}}$ were negative to the resting potential and would depolarize an $\mathrm{ON}$ cell if $\mathrm{E}_{\mathrm{Cl}}$ were positive to the resting potential. Indeed, $\mathrm{E}_{\mathrm{C} 1}$ was positive when measured by chloride electrode in ON cells of the intact mudpuppy retina (Miller and Dacheux, 1983). However, $\mathrm{E}_{\mathrm{Cl}}$ was always negative when assessed by measuring the GABA reversal potential in somas of isolated mammalian bipolar cells (Suzuki et al., 1990; Yamashita and Wässle, 1991b). Possibly a negative $\mathrm{E}_{\mathrm{Cl}}$ in the

Received May 23, 2000; revised July 19, 2000; accepted Aug. 4, 2000.

This work was supported by National Institutes of Health Grants EY00828, EY11105, and NS36296. We thank Madeleine Johnson for her contributions to the early stages of this project, Sally Shrom and Dr. Jian Li for electron microscopy, and Sharron Fina for preparing this manuscript.

Correspondence should be addressed to Noga Vardi at the above address. E-mail: noga@retina.anatomy.upenn.edu.

Copyright (C) 2000 Society for Neuroscience $0270-6474 / 00 / 207657-07 \$ 15.00 / 0$ bipolar axon terminals, which all intensely express ligand-gated anion channels $\left(\mathrm{GABA}_{\mathrm{A}}, \mathrm{GABA}_{\mathrm{C}}\right.$, and glycine receptor), dominates these compact neurons (only $50 \mu \mathrm{m}$ between dendritic and axonal tips). If so, possible differences in $\mathrm{E}_{\mathrm{Cl}}$ between dendritic and axonal compartments could not be resolved by somal recordings.

$\mathrm{E}_{\mathrm{Cl}}$ depends on intracellular chloride concentration, which appears to be regulated primarily by two transporters, an Na-K-Cl cotransporter (NKCC) that normally accumulates chloride and a $\mathrm{K}-\mathrm{Cl}$ cotransporter (KCC) that normally extrudes chloride (for review, see Russell, 2000). Certain neurons and epithelial cells with $\mathrm{E}_{\mathrm{C} 1}$ positive to the resting potential express $\mathrm{NKCC}$, whereas neurons with an $\mathrm{E}_{\mathrm{Cl}}$ negative to the resting potential express $\mathrm{KCC} 2$ (the neuron-specific isoform). Accordingly, if $\mathrm{NKCC}$ and KCC2 are the primary $\mathrm{Cl}^{-}$transporters in bipolar cells, we predicted that $\mathrm{OFF}$ dendrites should express $\mathrm{KCC} 2$ and $\mathrm{ON}$ dendrites should express NKCC. Here, we confirm this prediction by confocal and electron microscopy. We also show that NKCC and KCC2 are polarized at opposite poles of the same neuron (rod ON bipolar cell). This suggests that GABA depolarizes the cell at one end (dendrite) and hyperpolarizes at the other (axon terminal).

\section{MATRIALS AND METHODS}

\section{Immunoblots}

Membranes were prepared from freshly dissected tissue using differential centrifugation. Briefly, tissue was homogenized in 1-40 $\mathrm{ml}$ of homogenization buffer (in mM: 250 sucrose, 10 Tris, 10 HEPES, and 1 EDTA, pH adjusted to 7.2 at $24^{\circ} \mathrm{C}$ ) containing protease inhibitors. After 10 strokes in a glass Teflon homogenizer, the homogenate was centrifuged at $7000 \mathrm{rpm}$ for $10 \mathrm{~min}$ at $4^{\circ} \mathrm{C}$ (Sorval RC5, SS-34 rotor). The supernatant was centrifuged at $20,000 \mathrm{rpm}$ for $30 \mathrm{~min}$ at $4^{\circ} \mathrm{C}$. The final pellet was resuspended in $\sim 100-500 \mu$ l of homogenization buffer with protease inhibitors and stored at $-80^{\circ} \mathrm{C}$. Protein concentration was determined using a Micro-BCA protein kit (Pierce, Rockford, IL). Membrane proteins were resolved by SDS-PAGE using a 7.5\% Tricine gel system. Gels were electrophoretically transferred from unstained gels to polyvinylidene difluoride (PVDF) membranes (Immobilon P; Millipore, Bedford, MA) in transfer buffer (192 $\mathrm{mm}$ glycine, $25 \mathrm{~mm}$ Tris-Cl, $\mathrm{pH} 8.3$, and $15 \%$ methanol) for $5 \mathrm{hr}$ at $50 \mathrm{~V}$ using a Bio-Rad (Hercules, CA) Trans-Blot tank apparatus. PVDF-bound protein was visualized by staining with Coomassie brilliant blue R-250. The PVDF membrane was blocked in PBS-milk (7\% nonfat dry milk and $0.1 \%$ Tween 20 in PBS, pH 7.4) for $1 \mathrm{hr}$ and then incubated in PBS-milk with an anti-NKCC monoclonal antibody (T4) (Lytle et al., 1995) or affinity-purified anti-KCC2 polyclonal antibodies (Williams et al., 1999) for $2 \mathrm{hr}$ at $24^{\circ} \mathrm{C}$. After three $10 \mathrm{~min}$ washes in PBS-milk, the PVDF membrane was incubated with secondary antibody [horseradish peroxidase (HRP)-conjugated goat anti-mouse IgG; Amersham Pharmacia Biotech, Arlington Heights, IL] for $2 \mathrm{hr}$ at $24^{\circ} \mathrm{C}$ in PBS-milk. After three washes in 
PBS-0.1\% Tween 20, bound antibody was detected using an enhanced chemiluminescence assay (NEN, Boston, MA).

\section{Immunocytochemistry}

Eye cups from adult rhesus monkey (obtained from Covance Research Products Inc., Alice, TX) were fixed for $1 \mathrm{hr}$ in $4 \%$ paraformaldehyde diluted in $0.1 \mathrm{M}$ phosphate buffer at $\mathrm{pH}$ 7.4. Eyes from adult rat, mouse, guinea pig, or rabbit were removed under deep anesthesia [for rat and rabbit, pentobarbital $(45 \mu \mathrm{g} / \mathrm{gm})$; for mouse, mixture of ketamine $(85 \mu \mathrm{g} / \mathrm{gm})$ and xylazine $(13 \mu \mathrm{g} / \mathrm{gm})$; and for guinea pig, ketamine (40 $\mu \mathrm{g} / \mathrm{gm})$, xylazine $(8 \mu \mathrm{g} / \mathrm{gm})$, and pentobarbital $(35 \mu \mathrm{g} / \mathrm{gm})]$. Anesthesia was injected intraperitoneally. Animals were killed by anesthetic overdose (three times the initial doses). Animals were treated in compliance with federal regulations and University of Pennsylvania policy. For most experiments, rodent retinas were fixed in buffered $4 \%$ paraformaldehyde containing $0.01 \%$ glutaraldehyde for $1 \mathrm{hr}$ at room temperature.

Light microscopy. Tissue was cryoprotected with $30 \%$ sucrose in phosphate buffer (overnight), frozen in a mixture of Tissue Freezing Medium (Electron Microscopy Sciences, Ft. Washington, PA) and $20 \%$ sucrose $(1: 2)$, and cryosectioned vertically at $10 \mu \mathrm{m}$. Sections were then stained according to a standard protocol: soak in diluent containing $0.1 \mathrm{M}$ phosphate buffer, $10 \%$ normal goat serum, $5 \%$ sucrose, and $0.3 \%$ Triton $\mathrm{X}-100$; incubate in primary antibody overnight at $4^{\circ} \mathrm{C}$ (anti-KCC2, 1:200-1000; anti-NKCC, $1: 3000)$; wash and incubate $3 \mathrm{hr}$ in a secondary antibody conjugated to fluorescent marker or HRP. Sections with fluorescent markers were mounted in Vectashield (Vector Laboratories, Burlingame, CA). Sections with HRP markers were reacted with $\mathrm{H}_{2} \mathrm{O}_{2}$ plus 3, $3^{\prime}$-diaminobenzidine tetrahydrochloride (DAB) and mounted in glycerol. Sections were visualized with a confocal microscope (Leica, Nussloch, Germany).

Double-labeling. Sections were incubated simultaneously in two primary antibodies, one a marker (raised in mouse or rabbit) and the other a transporter, anti-KCC2 (raised in rabbit) or anti-NKCC (raised in mouse). Sections were then incubated simultaneously in two secondary antibodies, an $\mathrm{F}(\mathrm{ab})_{2}$ fragment conjugated to fluorescein isothiocyanate (FITC) and another $\mathrm{F}(\mathrm{ab})_{2}$ fragment conjugated to lisamine rhodamine. Double-labeling for parvalbumin and NKCC (both raised in mouse) was done by incubating sections sequentially as follows: anti-NKCC, rinse, anti-mouse $\mathrm{F}(\mathrm{ab})$ fragments conjugated to $\mathrm{Cy} 3$, rinse, anti-parvalbumin, rinse, and antimouse IgG conjugated to FITC. Control experiments in which anti-parvalbumin was omitted had no FITC stain.

Electron microscopy. Fixative was $4 \%$ paraformaldehyde and $0.01 \%$ glutaraldehyde in $0.12 \mathrm{M}$ phosphate buffer. After cryoprotection, eyecups were freeze-thawed three times, embedded in $4 \%$ agarose, and vibratome sectioned at $100 \mu \mathrm{m}$. Sections were processed as for light microscopy, but Triton X-100 was omitted or used at $0.1 \%$ for only $30 \mathrm{~min}$ at room temperature. Incubation in primary antibody was extended to $2-3 \mathrm{~d}$. DAB reaction product was silver-intensified and then gold-substituted (modified from van den Pol, 1988; Johnson and Vardi, 1998). The tissue was then osmicated ( $2 \%$ osmium tetroxide, $60 \mathrm{~min}$ ), stained with $1 \%$ uranyl acetate in $70 \%$ ethanol (60 min), dehydrated in ethanol, soaked in propylene oxide, and embedded in Epon 812. Ultrathin sections were mounted on Formvar-coated slot grids and counterstained with heavy metals.

Antibodies. The antibodies used are as follows: anti-KCC2, a polyclonal antibody raised in rabbit against a 112 amino acid sequence of the $\mathrm{C}$ terminus of rat KCC2; anti-NKCC (clone T4), a mouse monoclonal that recognizes all known isoforms (Lytle et al., 1995); anti-parvalbumin, mouse monoclonal (Sigma, St. Louis, $\mathrm{MO}$ ); and anti-protein kinase C (PKC), mouse monoclonal (Amersham Pharmacia Biotech). For several antigens, we used two different antibodies, one raised in rabbit for double-labeling with anti-NKCC and the other raised in mouse for double-labeling with anti-KCC2. These were as follows: anti-human mGluR6, a polyclonal antibody raised in rabbit and in mouse against the $\mathrm{C}$ terminus (Vardi et al., 2000); anti- $\mathrm{G}_{\alpha \mathrm{o}}$, a polyclonal raised in rabbit

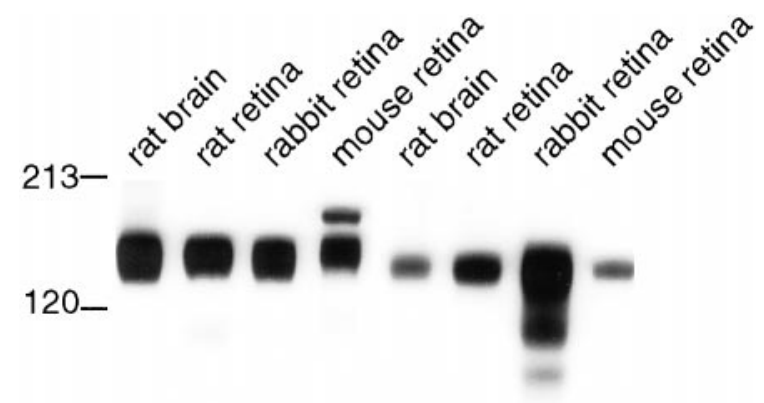

$76-$

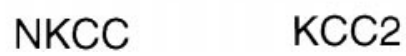

Figure 1. Retina expresses two chloride transporters: NKCC and KCC2. Anti-N KCC recognized a single band $(\sim 160 \mathrm{kDa})$ in retina and brain. The second band in mouse tissue is attributed to secondary antibody, which was anti-mouse. Anti-KCC2 recognized a single band $(\sim 140 \mathrm{kDa})$ in retina and brain. Multiple bands in rabbit tissue are attributed to reaction with secondary antibody, which was anti-rabbit.

against the $\mathrm{C}$ terminus (gift of Dr. D. Manning, University of Pennsylvania), and a mouse monoclonal against the purified bovine protein (MAB 3071; Chemicon) (Li et al., 1995); and anticalbindin-D (28 kDa), a monoclonal (clone CL-300; Sigma) and a polyclonal (Swant). Secondary antibodies conjugated to fluorescent markers were from Jackson ImmunoResearch (West Grove, PA), and those conjugated to HRP were from Protos Immunoresearch (San Francisco, CA).

\section{RESULTS}

\section{Both cation chloride cotransporters are expressed in retina}

The membrane fractions of retina and brain (mouse, rat, and rabbit) were probed by SDS-PAGE Western blots with antibodies to both cation chloride cotransporters $\mathrm{NKCC}$ and $\mathrm{KCC} 2$. In all tissues, NKCC was detected as a band at $\sim 160 \mathrm{kDa}$ and KCC2 as a band at $\sim 140 \mathrm{kDa}$ (Fig. 1). Each band corresponded to the predicted molecular weight of the transporter. Expression levels were similar in retina and brain. Thus, both transporters are expressed abundantly in retina.

\section{The two transporters distribute differently across retinal layers}

In the outer plexiform layer (OPL), antibodies to both transporters stained strongly but quite differently (Fig. 2). Anti-NKCC stained throughout the layer, being punctate in the outer half and diff use in the inner half. Anti-KCC2 stained primarily the middle stratum, distributing in a punctate manner in short rows beneath the cone pedicles. This pattern resembled staining for ligand-gated chloride

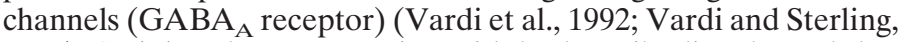
1994). Staining the same section with both antibodies showed that the two cotransporters do not colocalize (Fig. 3, middle column, bottom).

In the inner nuclear layer (INL), NKCC staining was negative, but anti-KCC2 stained somas of the upper two tiers. In the inner plexiform layer (IPL), NKCC staining was negative or weak, and anti-KCC2 stained strongly in a punctate manner, distributing evenly across the layer except for a negative band in the middle strata. In the ganglion cell layer, NKCC staining was negative in the ganglion cell somas but positive in the axons, whereas KCC2 staining was positive in ganglion cell somas and dendrites but negative in the axons.

Anti-KCC2 applied to rat, rabbit, and monkey retina gave similar results. Staining was reduced or completely abolished in monkey retina when the antibody was preabsorbed with its immunogenic peptide (1-10 $\mu \mathrm{g} / \mathrm{ml})$. Because the anti-N KCC antibody was mono- 


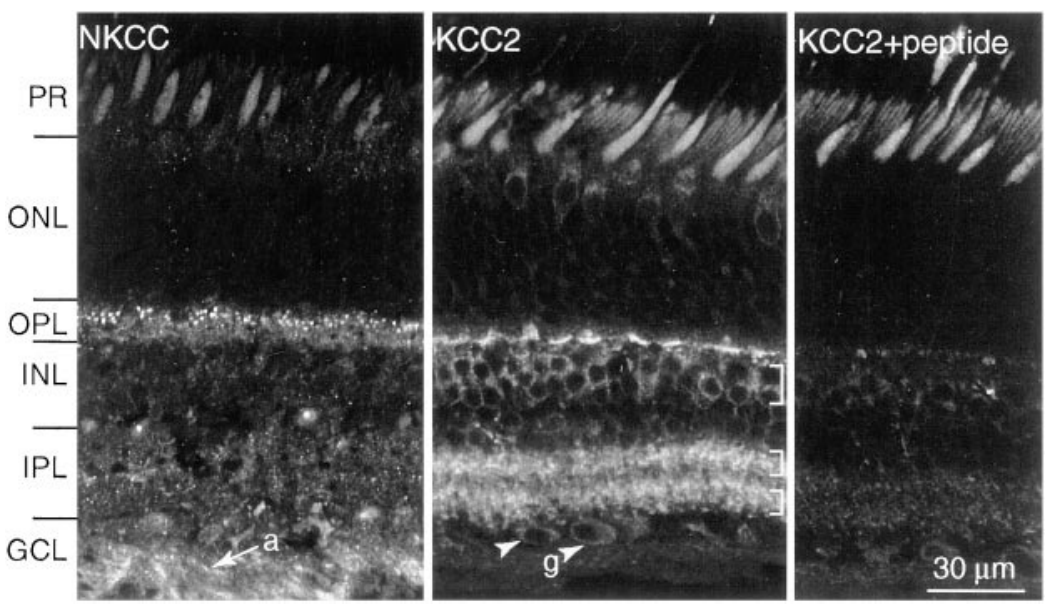

Figure 2. NKCC and KCC2 distribute differently (monkey). Left, Anti-NKCC strongly stains the OPL and ganglion cell axons $(a)$. Stain is punctate in the upper OPL and diff use in the lower OPL. Stain is weak in the IPL. Middle, Anti-KCC2 strongly stains the OPL as fine puncta that form a "dash " just beneath each cone terminal. Stain is absent in the region above the cone terminals in which rod terminals contact rod bipolar dendrites. Stain in the INL is restricted to the two upper tiers (brackets). Stain in the IPL is also punctate, forming two thick bands (brackets). Weak staining is also present in the ganglion cell somas $(g)$. Right, Anti-KCC2 preabsorbed with the immunogenic peptide $(1 \mu \mathrm{g} / \mathrm{ml})$ reduced staining of the synaptic layers but did not alter the diffuse stain in the photoreceptor inner segments. $P R$, Photoreceptor; $O N L$, outer nuclear layer; $G C L$, ganglion cell layer. Confocal, $40 \times$, oil immersion.
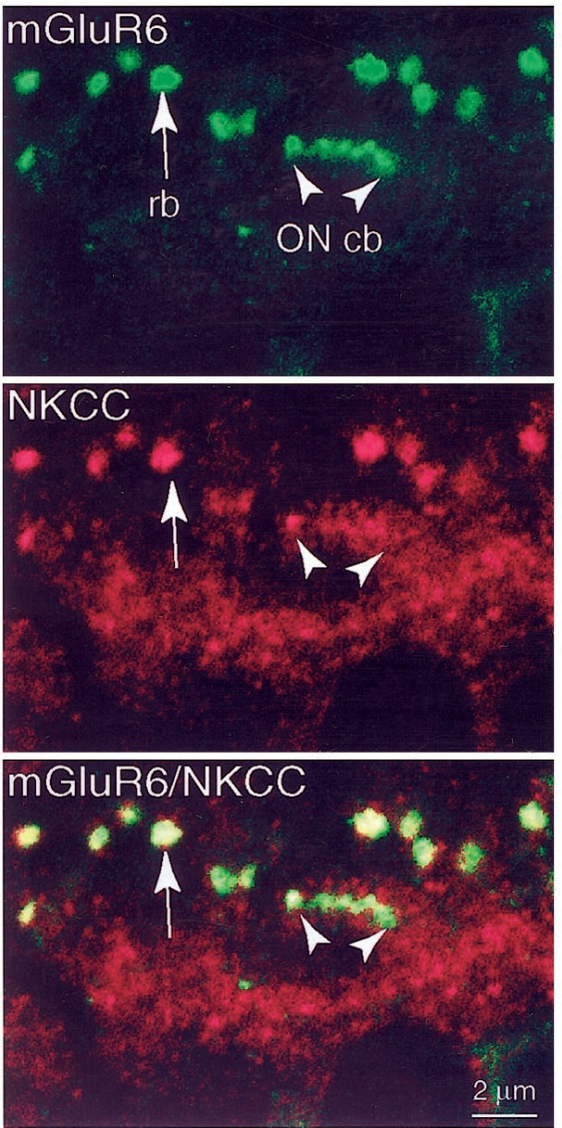
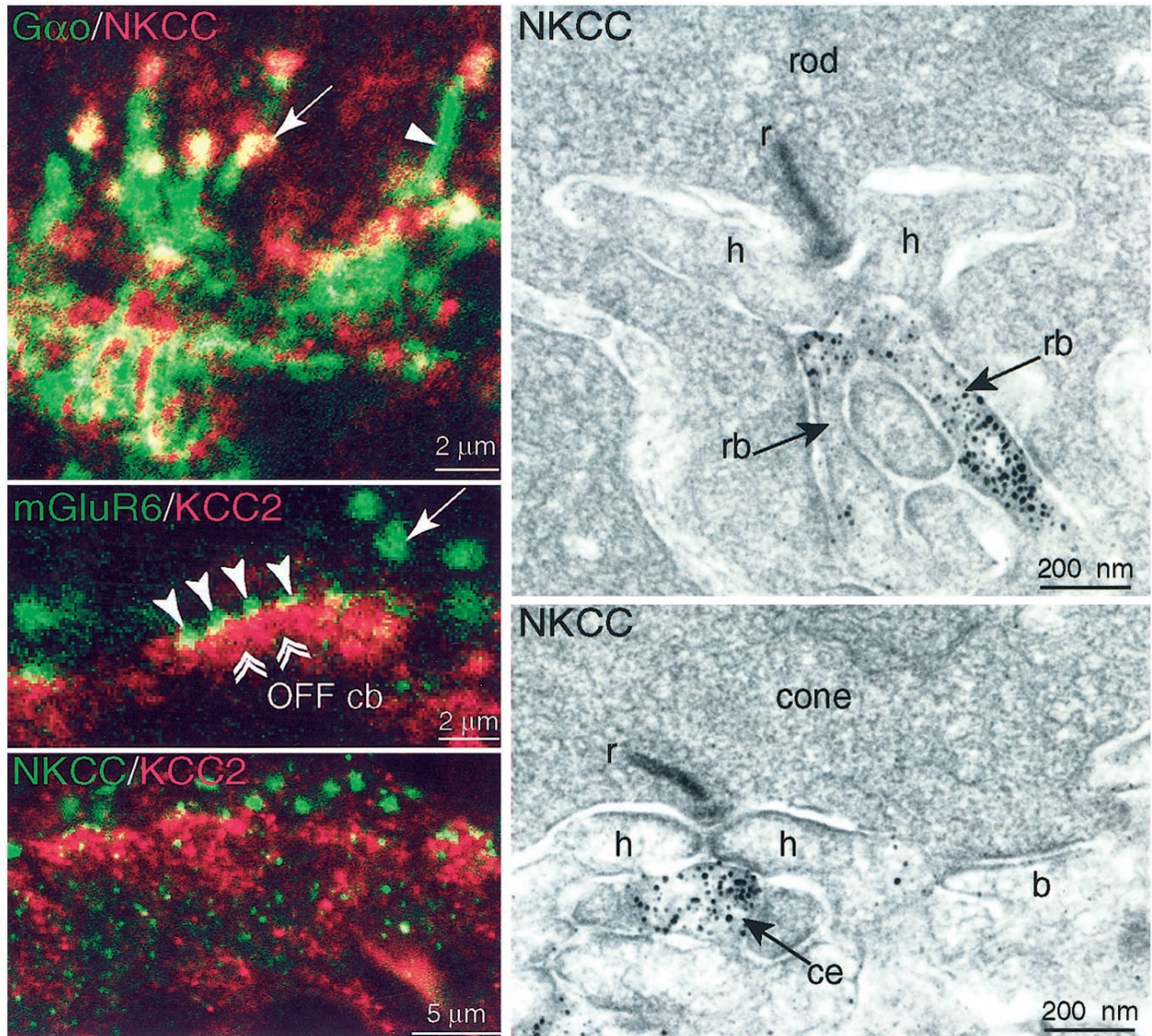

Figure 3. ON dendritic tips express NKCC but not KCC2 (monkey). Left column, Top, Anti-mGluR6 (green) stains large puncta ( $r b$ ), each representing a cluster of rod bipolar dendritic tips that invaginate a rod terminal. Also stained are smaller puncta $(O N c b)$, each representing the dendritic tip of an ON cone bipolar that invaginates a cone terminal. Middle and bottom, Anti-NKCC (red) stains the same structures as anti-mGluR6. Confocal, $100 \times$, oil immersion. Middle column, Top, Anti-G ${ }_{\alpha \mathrm{o}}$ (green) stains the rod bipolar dendritic tips (arrow) and their shafts (arrowhead). Anti-NKCC (red) colocalizes with $\mathrm{G}_{\alpha \mathrm{o}}$ only in the dendritic tips. Thus, NKCC is sharply confined to the dendritic tips. Middle, Anti-mGluR6 (green) identifies ON dendritic tips in which they invaginate photoreceptor terminals (rod, arrow; cone, arrowheads). The ON tips are negative for anti-KCC2 (red), which instead stains the OFF tips at the base of the cone terminal (double arrowheads). Bottom, Anti-NKCC (green) and -KCC2 (red) are not colocalized. Right column, Electron micrographs of a rod and a cone. Rod bipolar dendritic tips that invaginate the rod $(r b)$ and central elements at the cone synaptic complex ( $c e$ ) are stained. A dendrite that formed a basal contact $(b)$ did not stain. $r$, Ribbon; $h$, horizontal cell lateral process.

clonal (and thus recognized a single epitope), preabsorption would not test specificity. Therefore, we tested specificity by applying the antibody against a wider range of species (mouse, rat, rabbit, guinea pig, cat, baboon, and macaque), always with similar results in the outer plexiform layer. However, in rodent retina, ganglion cell somas and their axons did stain for NKCC. We conclude that the highly conserved staining patterns of both antibodies represent the true localization of the transporters. The next step was to determine which cell types expressed the transporters, and we did this by comparing their staining patterns with those of established markers.

\section{The two transporters are expressed differently by dendrites of ON and OFF bipolar cells}

The dendritic tips of ON bipolar cells were identified by their expression of mGluR6 (Vardi et al., 2000) and $\mathrm{G}_{\alpha \mathrm{o}}$ (Vardi, 1998). The cone bipolar tips can be recognized because they end in the middle stratum of the outer plexiform layer where they invaginate 
Figure 4. OFF dendrites express $\mathrm{KCC} 2$ (monkey, periphery). Left panel, Electron micrograph of anti-KCC2 in OFF dendrite forming a basal contact with a cone. A central element (ce) did not stain. Middle and right panels, Anti-calbindin (Cal, green) specifically identifies the OFF cone bipolar DB3 (asterisk), whose dendrites (arrowhead) ascend toward the cone terminal Anti-KCC2 (red) stains the DB3 soma and also regions of the ascending dendrites.
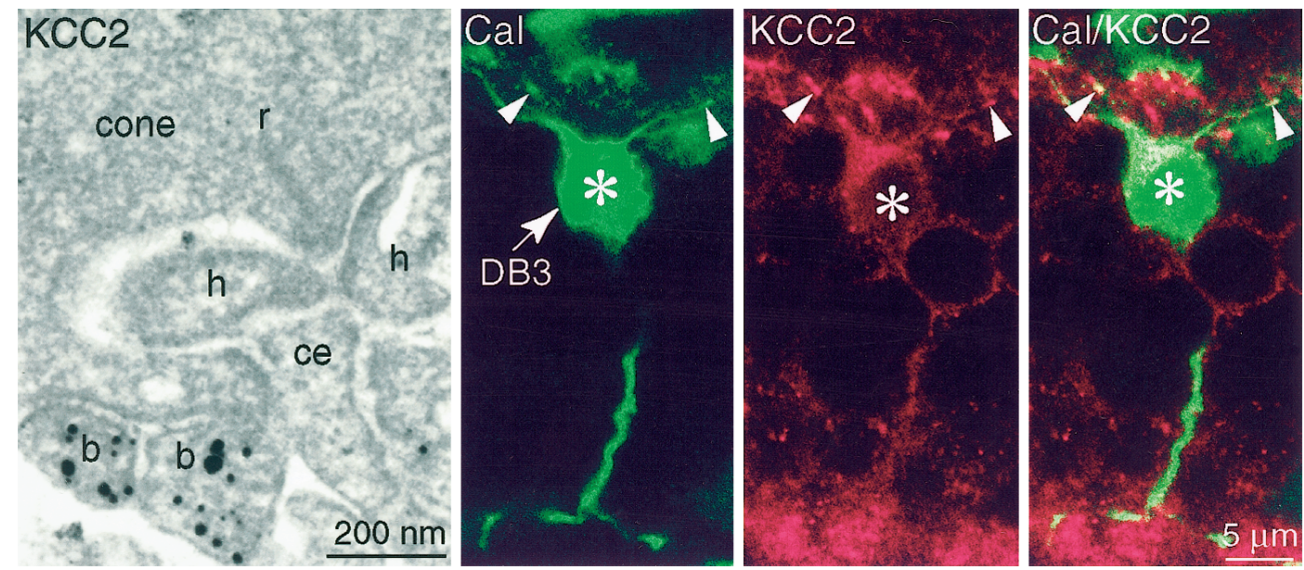

Figure 5. Rod bipolar axon terminals express KCC2 (rabbit). Left panel, AntiPKC (green) identifies the rod bipolar soma (asterisks), axon (arrowheads), and terminal (arrows). Anti-KCC2 (red) lightly stains the soma, barely stains the axon, but strongly stains the terminal (yellow, arrows). Middle and right panels, Higher magnification shows rod bipolar axon weakly stained but terminal strongly stained at the plasma membrane. Confocal, $100 \times$.
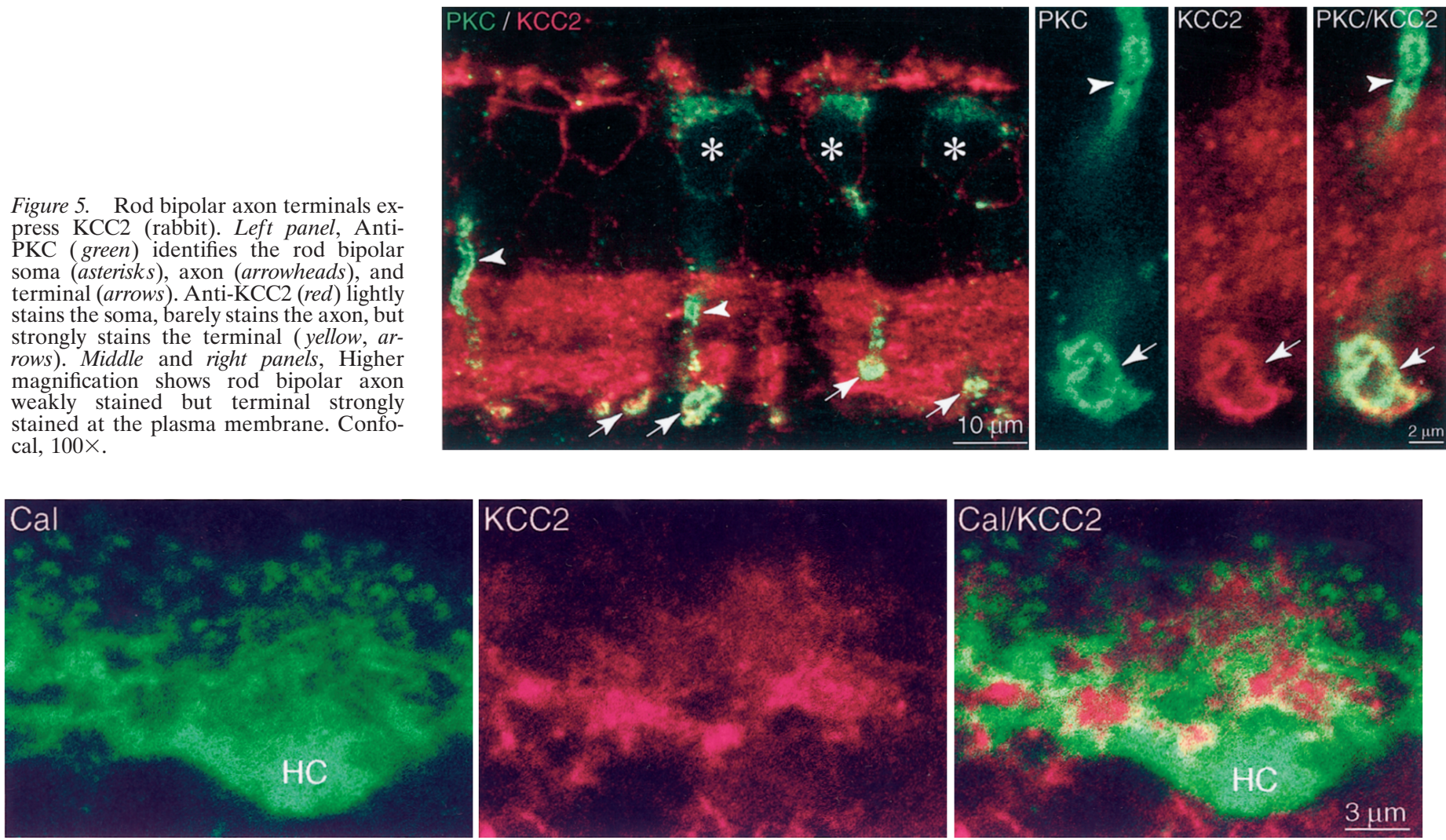

Figure 6. Horizontal cells do not express KCC2 (rat). Anti-calbindin ( Cal, green) identifies the horizontal cell soma (HC) and dendrites, including the tips. Anti-KCC2 (red) does not colocalize with calbindin. Although some yellow might suggest colocalization, it always appears at the border between green and red processes and is thus attributable to optical blur.

the cone pedicles. The rod bipolar dendritic tips end higher where they invaginate the rod spherules. Having marked the ON bipolar tips with anti-mGluR6 or anti-G ${ }_{\alpha \mathrm{o}}$, we applied anti-NKCC. NKCC sharply colocalized with mGluR6 (Fig. 3, left column) and with the tips of $\mathrm{G}_{\alpha \mathrm{o}}$-stained dendrites. It did not localize with $\mathrm{ON}$ dendritic shafts (Fig. 3, middle column, top). Electron microscopy confirmed that dendritic tips of rod bipolar cells and ON cone bipolar cells were stained for NKCC (Fig. 3, right column). Thus, both types of $\mathrm{ON}$ bipolar (rod and cone) sharply localize NKCC to the tips of their dendrites. These dendrites did not express $\mathrm{KCC} 2$ because double-staining for either mGluR6 and KCC2 (Fig. 3, middle column, middle) or both transporters did not colocalize (Fig. 3, middle column, bottom).

The tips of OFF cone bipolar occupy the stratum just beneath the cone terminals. This stratum was stained when we applied antiKCC2. To determine whether the stained processes in this stratum were OFF bipolar dendrites, we examined tissue by electron mi- croscopy (Fig. 4, left). In monkey peripheral retina, stained dendrites formed basal contacts corresponding to the sites of OFF bipolar cells (Dowling and Boycott, 1966; Kolb and Nelson, 1995; Calkins et al., 1996; Chun et al., 1996). We also used anti-calbindin to stain a type of OFF bipolar cell (DB3) (Grünert et al., 1994). This type expressed KCC2 strongly in soma and dendrites (Fig. 4) but also in the axon terminal. Thus, OFF cone bipolar cells express $\mathrm{KCC} 2$ and localize it to their dendritic tips.

\section{The two transporters distribute to opposite poles of an ON bipolar cell}

ON bipolar cells raise a special problem because they express ligand-gated anion channels both on their dendrites in which GABA presumably depolarizes and also on their axon terminals in which GABA hyperpolarizes (Tachibana and Kaneko, 1984, 1987) (for review, see Freed, 1992). Having shown that NKCC is present in ON dendritic tips, but not in the axon terminals (Figs. 2, 3), we 

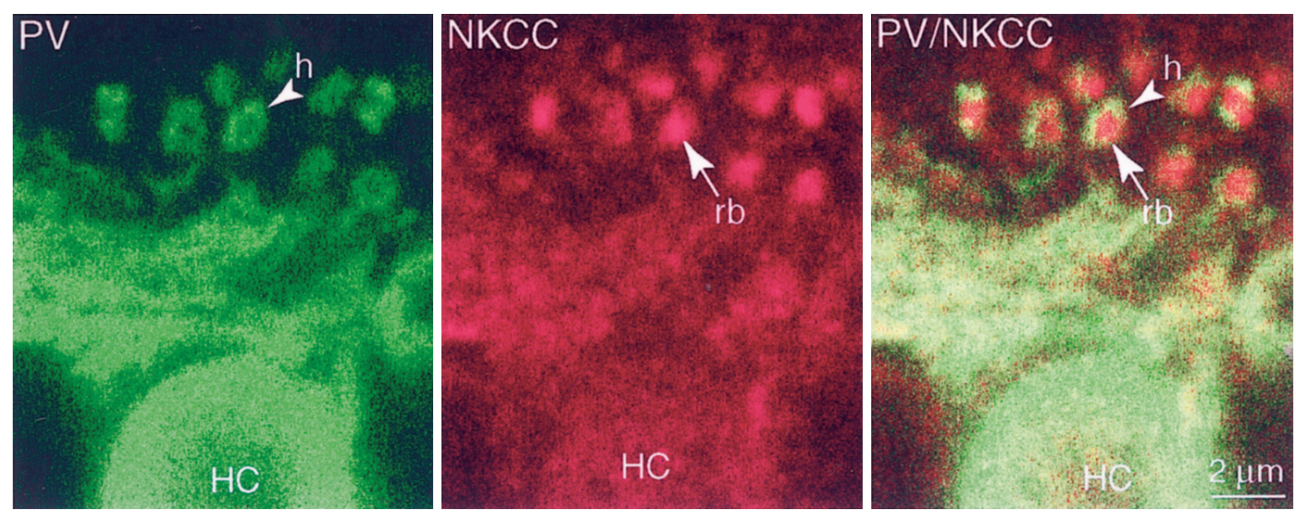

Figure 7. Horizontal cells express NKCC but not at the dendritic tips (monkey). Antiparvalbumin $(P V$, green) identifies the horizontal cell soma $(H C)$ and its dendritic tips that invaginate the photoreceptor terminals (h). Anti-NKCC (red) stains the horizontal cell soma and dendrites, colocalizing with anti-parvalbumin (yellowish, right). Although anti-NKCC also stains invaginating processes within the rod $(r b$, middle), the stain did not colocalize with parvalbumin (right, green vs red). Apparently, the stain for NKCC represents only ON bipolar tips (see Fig. 3), and horizontal cell tips do not express NKCC.

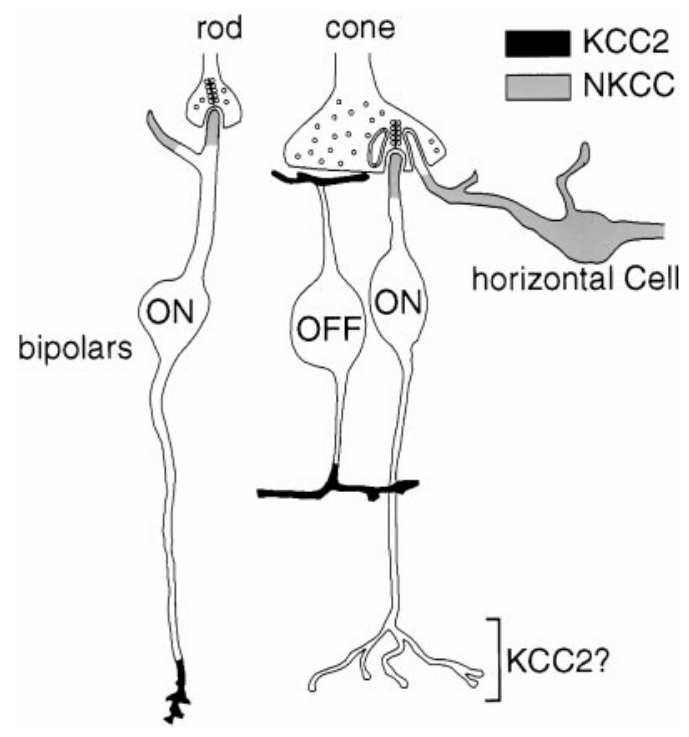

Figure 8. Summary diagram. ON bipolar dendritic tips and horizontal cells express NKCC. OFF bipolar dendritic tips and rod bipolar axon terminals express KCC2; cone bipolar axon terminals probably also express KCC2. Neither photoreceptors nor the invaginating tips of horizontal cell processes express a chloride transporter.

wondered whether $\mathrm{ON}$ axon terminals might express KCC2. To test this, we identified the soma and axon terminal of an ON cell (rod bipolar) with antibody to PKC (Negishi et al., 1988). Anti-KCC2 weakly stained the rod bipolar soma but strongly stained the axon terminal (monkey and rabbit), localizing to the plasma membrane (Fig. 5). Thus, an ON rod bipolar cell targets N KCC to the dendrite and KCC2 to the axon. This supports the idea that GABA depolarizes the dendrites (because NKCC maintains $\mathrm{E}_{\mathrm{Cl}}>\mathrm{E}_{\text {rest }}$ ) and hyperpolarizes the axon terminal (because KCC2 maintains $\mathrm{E}_{\mathrm{Cl}}<$ $\mathrm{E}_{\text {rest }}$ ).

\section{The two transporters are expressed differently by horizontal cells}

The expression of cation chloride cotransporters by horizontal cells was of special interest because $\mathrm{E}_{\mathrm{Cl}}$ has been measured (see Discussion). We identified horizontal cells by immunostaining for parvalbumin (monkey; Röhrenbeck et al., 1987) or calbindin (rat and rabbit; Pasteels et al., 1990; Mitchell et al., 1995). Anti-KCC2 did not colocalize to any part of the cell (Fig. 6). However, antiNKCC (monkey, rat, and rabbit) did colocalize in somas and dendrites (Fig. 7). These results, combined with the observation that anti-KCC2 and anti-N KCC applied together did not colocalize in the horizontal cell stratum suggest that horizontal cells express only NKCC (but see Vu et al., 2000). Curiously, the fine horizontal cell spines that invaginate the photoreceptor terminal did not express NKCC (Figs. 3, EM, 7). Thus, within the invagination of a photoreceptor terminal, all punctate stain for NKCC represents ON bipolar dendritic tips.

\section{DISCUSSION}

We feel confident that the staining patterns described here represent the actual expression of the two cation chloride cotransporters KCC2 and NKCC (Fig. 8). First, their amino acid sequences are well conserved across mammalian species, and recognition of these sequences by the present antibodies has been established in other tissues (Lytle et al., 1995; Williams et al., 1999). Second, in retina of three species, each antibody recognized a single protein band of the expected molecular weight, and the staining pattern for each antibody was nearly identical in up to seven mammalian species. Third, preabsorbtion with the immunizing peptide for KCC2 eliminated staining. Finally, both antibodies localized to the expected subcellular locus for these transporters i.e., the plasma membrane (Fig. 5). The NKCC antibody recognizes two isoforms, but one of these (NKCC2) is expressed only in kidney (Gamba et al., 1994; Payne and Forbush, 1994); therefore the isoform in retina is probably NKCC1.

\section{Evidence that NKCC and KCC2 contribute to $E_{C I}$}

In most neurons, $\mathrm{E}_{\mathrm{Cl}}$ is negative to $\mathrm{E}_{\text {rest }}$, so opening a chloride conductance causes $\mathrm{Cl}^{-}$influx and thus a hyperpolarizing postsynaptic potential (Eccles, 1964). Yet in certain neurons, $\mathrm{E}_{\mathrm{Cl}}$ is positive to $\mathrm{E}_{\text {rest }}$, so opening a chloride conductance causes $\mathrm{Cl}^{-}$efflux and thus a depolarizing postsynaptic potential. Neurons with positive $\mathrm{E}_{\mathrm{Cl}}$ include the following: developing hippocampal pyramidal cells, suprachiasmatic neurons at day time, retinal horizontal cells, and Rhohon-Beard spinal neurons (Andersen et al., 1980; Bixby and Spitzer, 1982; Perlman and Normann, 1990; Kamermans and Werblin, 1992; Wagner et al., 1997).

Recent studies suggest that $\mathrm{E}_{\mathrm{Cl}}$ can be maintained negative or positive to equilibrium $\left(\mathrm{E}_{\mathrm{C} 1} \neq \mathrm{E}_{\text {rest }}\right)$ primarily by two chloride transporters, NKCC and KCC2. For example, as hippocampal neurons mature and $\mathrm{E}_{\mathrm{Cl}}$ switches from positive to negative relative to $\mathrm{E}_{\text {rest }}$, these neurons reduce expression of NKCC (Plotkin et al., 1997) and begin to express KCC2 (Lu et al., 1999; Rivera et al., 1999). Similarly, as retinal ganglion cells mature and switch their GABA responses from depolarizing to hyperpolarizing (Bahring et al., 1994; Huang and Redburn, 1996; Fischer et al., 1998), they begin to express KCC2 (Vu et al., 2000). Functionally, Rivera et al. (1999) demonstrated that antisense oligonucleotide inhibition of KCC2 expression in mature hippocampal pyramidal neurons produced a significant positive shift in the reversal potential of the $\mathrm{GABA}_{\mathrm{A}}$ response. Also, cultured midbrain neurons shift $\mathrm{E}_{\mathrm{Cl}}$ from negative to positive when furosemide blocks $\mathrm{K}-\mathrm{Cl}$ cotransporter (Jarolimek et al., 1999), and Rohon-Beard neurons shift $\mathrm{E}_{\mathrm{Cl}}$ from positive to negative when bumetanide blocks Na-K-Cl cotransporter (Rohrbough and Spitzer, 1996). Although NKCC and KCC2 are likely the main neuronal $\mathrm{Cl}^{-}$transporters, there are other $\mathrm{Cl}^{-}$ transporters that may contribute to $\mathrm{Cl}^{-}$homeostasis, including $\mathrm{Na}^{+}$-independent and $\mathrm{Na}^{+}$-dependent $\mathrm{Cl}^{-} / \mathrm{HCO}_{3}{ }^{-}$exchangers 
(Kaila, 1994) and certain $\mathrm{Cl}^{-}$channels (ClC-2) (Smith et al., 1995; Staley et al., 1996; Enz et al., 1999).

Here, testing for both transporters in multiple cell types of one region in adult brain has allowed two important conclusions. First, we obtained systematic evidence that the polarity of $\mathrm{E}_{\mathrm{Cl}}$ correlates remarkably well with the cation chloride cotransporter that is expressed. For example, mature horizontal cells have a directly measured positive $\mathrm{E}_{\mathrm{Cl}}$ and depolarize to GABA (Miller and Dacheux, 1983; Djamgoz and Laming, 1987; Perlman and Normann, 1990; Blanco et al., 1996); they express NKCC. ON bipolar dendrites should have positive $\mathrm{E}_{\mathrm{Cl}}$ to explain the surround antagonism attributable to their $\mathrm{GABA}_{\mathrm{A}}$ receptors (Vardi and Sterling, 1994); they express NKCC. OFF bipolar dendrites and ganglion cells have a negative $\mathrm{E}_{\mathrm{Cl}}$ and hyperpolarize to GABA (Miller and Dacheux, 1983; Wässle et al., 1986; Tachibana and Kaneko, 1987; Müller et al., 1992; Fischer et al., 1998); they express KCC2. Second, we obtained evidence that different regions of certain neurons express different cation chloride cotransporters, and this permits differential responses to GABA. In the rod bipolar cell, the axon terminal expresses $\mathrm{KCC} 2$ in which GABA hyperpolarizes, and the dendritic tip expresses NKCC in which GABA presumably depolarizes. Thus, it appears that these cotransporters can maintain a precisely regulated chloride gradient, quite remarkably even in a compact cell as the rod bipolar cell ( $\sim 100 \mu \mathrm{m}$ long, $\sim 20 \mu \mathrm{m}$ wide $)$.

Intracellular chloride has rarely been measured directly but rather assessed by the polarity of voltage or current flow in response to activating a ligand-gated chloride conductance. Further direct measurements of intracellular chloride are needed, as well as the effects of blocking the transporters with appropriate concentrations of "loop" diuretics (Payne et al., 1995; Payne, 1997). However, even lacking these difficult measurements, one can reasonably conclude that the opposite effects of GABA on different neurons (or different parts of the same neuron) primarily depend on whether chloride is locally extruded or locally accumulated. More broadly, targeting specific transporters can be used to enhance the computational diversity of a particular transmitter-receptor pair.

\section{Other possible functions of the $\mathrm{Cl}^{-}$cotransporters in bipolar cells}

The differential distribution of NKCC and KCC2 in dendritic tips of $\mathrm{ON}$ and $\mathrm{OFF}$ bipolar cells supports our prediction that these two cell classes should exhibit opposite responses to GABA. However, it is conceivable that the depolarizing responses to GABA would exert a shunting inhibition and thus not contribute to the surround response. If this is the case, why would each cell type express a different $\mathrm{Cl}^{-}$cotransporter? In non-neuronal cells, the main function of the Na-K-Cl and $\mathrm{K}-\mathrm{Cl}$ cotransporters (primarily $\mathrm{NKCC} 1$ and $\mathrm{KCC} 1$ ) is to regulate cell volume, and both cotransporters can conceivably contribute to regulation of extracellular $\mathrm{K}^{+}$. It is possible that the neuronal isoforms localized here to different subcellular compartments ( $\mathrm{NKCC} 1$ and $\mathrm{KCC} 2$ ) also contribute to cation and water homeostasis. If so, ON and OFF bipolar classes may require different cotransporters because cation fluxes in these cells are inversely correlated; light closes cation channels in OFF bipolar cells and opens cation channels in ON bipolar cells.

\section{REFERENCES}

Andersen P, Dingledine R, Gjerstad L, Langmoen IA, Mosfeldt Laursen A (1980) Two different responses of hippocampal pyramidal cells to application of gamma-amino butyric acid. J Physiol (Lond) 305:279-296.

Ayoub GS, Lam DMK (1984) The release of gamma-aminobutyric acid from horizontal cells of the goldfish (Carassius auratus) retina. J Physiol (Lond) 355:191-214.

Bahring R, Standhardt H, Martelli EA, Grantyn R (1994) GABA activated chloride currents of postnatal mouse retinal ganglion cells are blocked by acetylcholine and acetylcarnitine: how specific are ion channels in immature neurons? Eur J Neurosci 6:1089-1099.

Bixby JL, Spitzer NC (1982) The appearance and development of chemosensitivity in Rohon-Beard neurones of the Xenopus spinal cord. J Physio (Lond) 330:513-536.
Blanco R, Vaquero CF, de la Villa P (1996) The effects of GABA and glycine on horizontal cells of the rabbit retina. Vision Res 36:3987-3995.

Calkins D, Tsukamoto Y, Sterling P (1996) Foveal cones form basal as well as invaginating contacts with diffuse ON bipolar cells. Vision Res 36:3373-3381.

Chappell RL, Malchow RP, Ripps H (1992) Perforated patch recordings from isolated skate bipolar cells. Biol Bull 183:347-348.

Chun M-H, Grünert U, Martin PR, Wässle H (1996) The synaptic complex of cones in the fovea and in the periphery of the macaque monkey retina. Vision Res 36:3383-3395.

de la Villa P, Kurahashi T, Kaneko A (1995) L-glutamate-induced responses and cGMP-activated channels in three subtypes of retinal bipolar cells dissociated from the cat. J Neurosci 15:3571-3582.

Djamgoz MBA, Laming PJ (1987) Micro-electrode measurements and functional aspects of chloride activity in cyprinid fish retina: extracellular activity and intracellular activities of L- and C-type horizontal cells. Vision Res 9:1481-1489.

Dowling JE, Boycott BB (1966) Organization of the primate retina: electron microscopy. Proc R Soc Lond B Biol Sci 166:80-111.

Eccles JC (1964) The physiology of synapses, pp 173-188. Berlin: Springer.

Enz R, Brandstätter JH, Wässle H, Bormann J (1996) Immunocytochemical localization of $\mathrm{GABA}_{\mathrm{C}}$ receptor rho subunits in the mammalian retina. J Neurosci 16:4479-4490.

Enz R, Ross BJ, Cutting GR (1999) Expression of the voltage-gated chloride channel ClC-2 in rod bipolar cells of the rat retina. J Neurosci 19:9841-9847.

Fischer KF, Lukasiewicz PD, Wong ROL (1998) Age-dependent and cell class-specific modulation of retinal ganglion cell bursting activity by GABA. J Neurosci 18:3767-3778.

Freed MA (1992) GABAergic circuits in the mammalian retina. In: Progress in brain research (Mize RR, Marc RE, Sillito AM, eds), pp 107-131. Amsterdam: Elsevier.

Gamba G, Miyanoshita A, Lombardi M, Lytton J, Lee W-S, Hediger MA, Herbert SC (1994) Molecular cloning, primary structure, and characterization of two members of the mammalian electroneutral sodium(potassium)-chloride cotransporter family expressed in kidney. J Biol Chem 269:17713-17722.

Greferath U, Grünert U, Müller F, Wässle H (1994) Localization of $\mathrm{GABA}_{\mathrm{A}}$ receptors in the rabbit retina. Cell Tissue Res 276:295-307.

Grünert U, Martin PR, Wässle H (1994) Immunocytochemical analysis of bipolar cells in the macaque monkey retina. J Comp Neurol 348:607-627.

Huang B, Redburn DA (1996) GABA-induced increases in $\left[\mathrm{Ca}^{2+}\right]_{\mathrm{i}}$ in retinal neurons of postnatal rabbits. Vis Neurosci 13:441-447.

Jarolimek W, Lewen A, Misgeld U (1999) A furosemide-sensitive $\mathrm{K}^{+}$. $\mathrm{Cl}^{-}$cotransporter counteracts intracellular $\mathrm{Cl}^{-}$accumulation and depletion in cultured rat midbrain neurons. J Neurosci 19:4695-4704.

Johnson MA, Vardi N (1998) Regional differences in GABA and GAD immunoreactivity in rabbit horizontal cells. Vis Neurosci 15:743-753.

Kaila K (1994) Ionic basis of $\mathrm{GABA}_{\mathrm{A}}$ receptor channel function in the nervous system. Prog Neurobiol 42:489-537.

Kamermans M, Werblin F (1992) GABA-mediated positive autofeedback loop controls horizontal cell kinetics in tiger salamander retina. J Neurosci 12:2451-2463.

Kaneko A (1970) Physiological and morphological identification of horizontal, bipolar and amacrine cells in goldfish retina. J Physiol (Lond) 207:623-633.

Kolb H, Nelson R (1995) The organization of photoreceptor to bipolar synapses in the outer plexiform layer. In: Neurobiology and clinical aspects of the outer retina (Djamgoz MBA, Archer SN, Vallerga S, eds), pp 273-296. London: Chapman \& Hall.

Koulen P, Brandstätter JH, Enz R, Bormann J, Wässle H (1998) Synaptic clustering of $\mathrm{GABA}_{\mathrm{C}}$ receptor $\rho$-subunits in the rat retina. Eur J Neurosci 10:115-127.

Li X, Mumby S, Greenwood A, Jope R (1995) Pertussis toxin-sensitive G-protein $\alpha$-subunits: production of monoclonal antibodies and detection of differential increases upon differentiation of PC12 and LA-N-5 cells. J Neurochem 64:1107-1117.

Lu J, Karadsheh M, Delpire E (1999) Developmental regulation of the neuronal-specific isoform of $\mathrm{K}-\mathrm{Cl}$ cotransporter $\mathrm{KCC} 2$ in postnatal rat brains. J Neurobiol 39:558-568.

Lytle C, Xu J-C, Biemesderfer D, Forbush BI (1995) Distribution and diversity of Na-K-Cl cotransport proteins: a study with monoclonal antibodies. Am J Physiol 269:C1496-C1505.

Miller RF, Dacheux RF (1983) Intracellular chloride in retinal neurons: measurement and meaning. Vision Res 23:399-411.

Mitchell CK, Rowe-Rendleman CL, Ashraf S, Redburn DA (1995) Calbindin immunoreactivity of horizontal cells in the developing rabbit retina. Exp Eye Res 61:691-698.

Müller F, Boos R, Wässle H (1992) Actions of GABAergic ligands on brisk ganglion cells in the cat retina. Vis Neurosci 9:415-425.

Nawy S, Jahr CE (1990) Suppression by glutamate of cGMP-activated conductance in retinal bipolar cells. Nature 346:269-271.

Negishi K, Kato S, Teranishi T (1988) Dopamine cells and rod bipolar cells contain protein kinase $\mathrm{C}$-like immunoreactivity in some vertebrate retinas. Neurosci Lett 94:247-252. 
Pasteels B, Rogers J, Blachier F, Pochet R (1990) Calbindin and calretinin localization in retina from different species. Vis Neurosci 5:1-16.

Payne JA (1997) Functional characterization of the neuronal-specific K-Cl cotransporter: implications for $\left[\mathrm{K}^{+}\right] \mathrm{o}$ regulation. Am J Physiol 273:C1516-C1525.

Payne JA, Forbush BI (1994) Alternatively spliced isoforms of the putative renal $\mathrm{Na}-\mathrm{K}-\mathrm{Cl}$ cotransporter are differentially distributed within the rabbit kidney. Proc Natl Acad Sci USA 91:4544-4548.

Payne JA, Xu JC, Haas M, Lytle CY, Ward D, Forbush III B (1995) Primary structure, functional expression, and chromosomal localization of the bumetanide-sensitive Na-K-Cl cotransporter in human colon. J Biol Chem 270:17977-17985.

Perlman I, Normann RA (1990) The effects of GABA and related drugs on horizontal cells in the isolated turtle retina. Vis Neurosci 5:469-477.

Plotkin MD, Snyder EY, Hebert SC, Delpire E (1997) Expression of the $\mathrm{Na}-\mathrm{K}-2 \mathrm{Cl}$ cotransporter is developmentally regulated in postnatal rat brains: a possible mechanism underlying GABA's excitatory role in immature brain. J Neurobiol 33:781-795.

Rivera C, Voipio J, Payne JA, Ruusuvuori E, Lahtinen H, Lamsa K, Pirvola U, Saarma M, Kaila K (1999) The $\mathrm{K}^{+} / \mathrm{Cl}^{-}$co-transporter $\mathrm{KCC} 2$ renders GABA hyperpolarizing during neuronal maturation. $\mathrm{Na}-$ ture 397:251-255.

Rohrbough J, Spitzer NC (1996) Regulation of intracellular $\mathrm{Cl}^{-}$levels by $\mathrm{Na}^{+}$-dependent $\mathrm{Cl}^{-}$cotransport distinguishes depolarizing from hyperpolarizing $\mathrm{GABA}_{\mathrm{A}}$ receptor-mediated responses in spinal neurons. J Neurosci 16:82-91.

Röhrenbeck J, Wässle H, Heizmann CW (1987) Immunocytochemical labelling of horizontal cells in mammalian retina using antibodies against calcium-binding proteins. Neurosci Lett 77:255-260.

Russell JM (2000) Sodium-potassium-chloride cotransport. Physiol Rev 80:211-276.

Schwartz EA (1982) Calcium-independent release of GABA from isolated horizontal cells of the toad retina. J Physiol (Lond) 323:211-227.

Shields CR, Tran MN, Wong ROL, Lukasiewicz PD (2000) Distinct ionotropic GABA receptors mediate presynaptic and postsynaptic inhibition in retinal bipolar cells. J Neurosci 20:2673-2682.

Shiells RA, Falk G (1990) Glutamate receptors of rod bipolar cells are linked to a cyclic GMP cascade via a G-protein. Proc R Soc Lond B Biol Sci 242:91-94.

Smith RL, Clayton GH, Wilcox CL, Escudero KW, Staley KJ (1995) Differential expression of an inwardly rectifying chloride conductance in rat brain neurons: a potential mechanism for cell-specific modulation of postsynaptic inhibition. J Neurosci 15:4057-4067.

Staley K, Smith R, Schaack J, Wilcox C, Jentsch TJ (1996) Alteration of
$\mathrm{GABA}_{\mathrm{A}}$ receptor function following gene transfer of the CLC-2 chloride channel. Neuron 17:543-551.

Suzuki S, Tachibana M, Kaneko A (1990) Effects of glycine and GABA on isolated bipolar cells of the mouse retina. J Physiol (Lond) 421:645-662.

Tachibana M, Kaneko A (1984) Gamma-aminobutyric acid acts at axon terminals of turtle photoreceptors: difference in sensitivity among cell types. Proc Natl Acad Sci USA 81:7961-7964.

Tachibana M, Kaneko A (1987) Gamma-aminobutyric acid exerts a local inhibitory action on the axon terminal of bipolar cells: evidence for negative feedback from amacrine cells. Proc Natl Acad Sci USA 84:3501-3505.

van den Pol AN (1988) Silver intensification of colloidal gold or horseradish peroxidase for dual ultrastructural immunocytochemistry. In: Molecular neuroanatomy (van Leeuwen FW, Buijs RM, Pool CW, Pach O, eds), pp 315-336. Amsterdam: Elsevier.

Vardi N (1998) Alpha subunit of $G_{0}$ localizes in the dendritic tips of ON bipolar cells. J Comp Neurol 395:43-52.

Vardi N, Sterling P (1994) Subcellular localization of GABA receptor on $_{\mathrm{A}}$ bipolar cells in macaque and human retina. Vision Res 34:1235-1246.

Vardi N, Masarachia P, Sterling P (1992) Immunoreactivity to GABA receptor in the outer plexiform layer of the cat retina. J Comp Neurol 320:394-397.

Vardi N, Duvoisin RM, Wu G, Sterling P (2000) Localization of mGluR6 to dendrites of ON bipolar cells in primate retina. J Comp Neurol 423:402-412.

Vu TQ, Payne JA, Copenhagen D (2000) Localization and developmental expression patterns of the neuronal $\mathrm{K}-\mathrm{Cl}$ cotransporter $(\mathrm{KCC} 2)$ in the rat retina. J Neurosci 20:1414-1423.

Wagner S, Castel M, Gainer H, Yarom Y (1997) GABA in the mammalian suprachiasmatic nucleus and its role in diurnal rhythmicity. Nature 387:598-603.

Wässle H, Voigt T, Schmidt M, Humphrey M (1986) Action and localization of neurotransmitters in the cat retina. Neurosci Res 4:S181-S195.

Werblin FS, Dowling JE (1969) Organization of the retina of the mudpuppy, Necturus maculosus. II. Intracellular recording. J Neurophysiol 32:339-355

Williams JR, Sharp JW, Kumari VG, Wilson M, Payne JA (1999) The neuron-specific K-Cl cotransporter, KCC2. J Biol Chem 274: $12656-12664$.

Yamashita M, Wässle H (1991a) Responses of rod bipolar cells isolated from the rat retina to the glutamate agonist 2-amino-4-phosphonobutyric acid (APB). J Neurosci 11:2372-2382.

Yamashita M, Wässle H (1991b) Reversal potential of GABA-induced currents in rod bipolar cells of the rat retina. Vis Neurosci 6:399-401. 